\title{
Otázka Pilátova: pojem „pravda“ u K. Čapka
}

\section{The Question of Pilat: The Notion of "Truth" in K. Čapek}

\author{
Hana Řehulková
}

\begin{abstract}
Abstrakt
Článek představuje Čapkovo pojetí pravdy z hlediska filozofie a standardní epistemologie. Na základě Čapkových teoretických i uměleckých textů se příspěvek snaží nalézt odpověd' na otázku "co je pravda" a podřadit ji korespondenční teorii pravdy.
\end{abstract}

\section{Klíčová slova}

Karel Čapek - pravda - korespondenční teorie

\begin{abstract}
The paper presents Čapek's conception of truth from the point of view of philosophy and standard epistemology. Based on Čapek's theoretical and artistic texts, the paper tries to find an answer to the question "what is truth" and subordinate it to the correspondence theory of truth.
\end{abstract}

\section{Keywords}

Karel Čapek - truth - the correspondence theory 
[...] píšu pořád a pořád to samé, jen kabát je trochu jiný. Opakuji se prostě. V celé své práci omílám do omrzení dvě zpola morální, zpola noetická témata. První je negativní Pilátovo: Co je to pravda? Druhé je pozitivní: Každý má pravdu. ${ }^{1}$

Pro Karla Čapka je téma pravdy, jak sám píše, významný, či dokonce nejvýznamnější námět vlastní tvorby umělecké, publicistické i teoretické. Přestože bylo Čapkovo dílo podrobeno již téměř vyčerpávajícímu zkoumání, pokusíme se představit jeho pojetí pravdy pohledem standardní epistemologie s pokusem vyložit jej ve vztahu k teoriím pravdy. ${ }^{2}$ Domníváme se totiž, že se jedná o kruciální téma Čapkova myšlení i tvorby a plné porozumění jeho pojetí pravdy je tak zásadní pro pochopení celého Čapkova díla, které se stalo součástí českého filozofického myšlení. ${ }^{3}$

Filozofický rozměr Čapkova bohatého a mnohostranného literárního díla je dán nejen obsahem a námětem jeho prací, ale i známou skutečností, že Čapek filozofii studoval. Jak píše J. Opelík:

[...] byl to převratný pohyb v současném výtvarném umění, spojený s nástupem kubismu a futurismu, co v Čapkovi vzbudilo potřebu sestoupit k hlubinným příčinám, souvislostem a zákonitostem tohoto pohybu, a tudíž i rozhodnutí věnovat se napřriště základní problematice poznávání a hodnocení, tedy filozofii. ${ }^{4}$

Nutno však rovněž dodat, že filozofie nebyla první Čapkovou studijní volbou. Původní zájem jej vedl ke studiu filologie, až poté přestoupil ke studiu dějin umění a estetiky. ${ }^{5}$ Disertační práce Objektivni metoda v estetice se zřením

1 ČAPEK, K. Musím dále..., s. 415. Čapkovo označení směrů v uvažování o pravdě za „negativní“ a „pozitivní“ není autorem samým v textu vysvětleno. Lze se domnívat, že se jedná o postoje mluvčích, na něž oba citáty odkazují. Pilátova negativistická pozice vyjadřující principiální nedosažitelnost absolutní pravdy tak stojí v protikladu k pirandellovskému (pozitivnímu) nacházení pravdy v sice roztříštěné, ale všudypřítomné podobě.

2 Na filozofický kontext Čapkova díla bylo upozorněno vícekrát. Za všechny lze připomenout práci Jana Zouhara „Filozofie, světový názor, tvorba“ uveřejněnou v souborné publikaci VLAŠÍN, Š. a kol. Kniha o Čapkovi... V této knize se však objevují texty převážně spíše přehledové než polemické.

3 Jak uvádí Jan Zouhar, hovoří se v českých podmínkách někdy o „české filozofii“ označující profesionální, školskou filozofii, nebo šířeji o „filozofickém myšlení“, kdy se k filozofické problematice vyjadřují nejen filozofové, ale i vědci, spisovatelé, politici. Srov. ZOUHAR, J. Dějiny českého filozofického myšleni..., s. 6.

4 OPELÍK, J. Cesty za vědou..., s. 37.

5 Během Čapkových studií přednášeli na Karlově univerzitě filozofii čtyři řádní profesoři: 
k výtvarnému uměni (1915) může rovněž navádět $\mathrm{k}$ domněnce, že filozofické otázky Čapka zajímaly, alespoň v době studií, především ve vztahu k umění. Čapkovi bytostně vlastní umělecký literární projev se však stal nástrojem vypořádání se s osobně naléhavými filozofickými otázkami, čímž se jeho dílo stalo jednak z uměleckého hlediska obsahově specifickým a současně filozoficky relevantním. I přes uměleckou formu tak lze nahlížet jeho dílo opodstatněně i z hlediska epistemologie, axiologie, etiky a estetiky.

S nadsázkou řečeno „osudnou“ se Čapkovi stala později publikovaná seminární práce o pragmatismu (Pragmatismus čili filozofie praktického života, $1918^{6}$ ), která jej sice zařadila do publikací o dějinách české filozofie, současně však zavdala prŕíčinu k neoprávněně zjednodušeným interpretacím, až dezinterpretacím Čapkova myšlení, proti kterým se Čapek opakovaně vymezoval. Další, neméně interpretačně nesnadný, zdroj jeho filozofických úvah lze poodhalit ze spolupráce a sympatií s T. G. Masarykem kulminujících v práci Hovory s TGM (1928-1935) a Mlčeni s TGM (1935). Společně s dalšími pracemi, recenzemi filozofické literatury, polemikami, přednáškami atd. skládá se s větši či menší interpretační námahou jako mozaika obraz Čapkových názorů a přesvědčení o filozofických otázkách, a to tam, kde jsou kladeny explicitně v textech teoretických, i tam, kde jsou obsaženy implicitně skryté a tušené v dílech uměleckých.

Pojmenovat, označit a podřadit tento mozaikový obraz filozofickým směrům či převést Čapkovo myšlení do filozofické terminologie je vděčným cílem badatelů různých oborů. V souvislosti s Čapkovým myšlením se hovoří o pragmatismu, relativismu, perspektivismu, instrumentalismu, pluralismu, vitalismu, socialismu a mnoha dalších „-ismech“, které se snaží Čapkovy názory definovat. To, že je výsledný obraz někdy poněkud rozpačitý, lze přičíst nejméně dvěma skutečnostem. Jednak snahy o zařazení Čapkova díla do vymezených myšlenkových směrů pramení z oborově rozličných pohledů, jejichž porozumění různým „-ismům“ může klást důraz na jiné aspekty. Jednak sám Čapek, ačkoliv se může takové tvrzení zdát opovážlivé, ve svých textech často vyjadřoval svá přesvědčení sice s vhledem a porozuměním pro zkoumaný problém, ale současně, osvobozen uměleckým či publicistickým žánrem od významové jednoznačnosti odborného textu, bez hlubšího závazku k vytvoření uceleného a nerozporného myšlenkového systému, čímž docházelo někdy i k výrokům

František Čáda, František Drtina, František Krejčí a T. G. Masaryk. Většinu kurzů absolvoval Karel Čapek u Fr. Čády a Fr. Krejčího. 
protikladným a v úzkém vidění vnitřně rozporným. Tuto skutečnost se pokusíme ukázat právě i na Čapkově hledání odpovědi na otázku „co je pravda“.

\section{Pozitivní: Každý má pravdu}

Obvykle se filozofický rozměr Čapkova díla vztahuje k jeho noetickým námětům, a to od Božich $m u k^{7}$ (1917) přes tzv. noetickou trilogii (1933-1934) až po nedokončenou práci Život a dílo skladatele Foltýna. M. Pohorský uvádí:

Otázka, jak člověk poznává lidi a věci kolem sebe, tedy noetická otázka, jež nepatř́ zrovna mezi běžné impulsy umělecké tvorby, zajímala Karla Čapka prozaika vlastně nepřetržitě. ${ }^{8}$

V čapkovské literatuře se v souvislosti se spisovatelovým zájmem o teorii poznání většinou hovoří o relativismu a pluralismu, ${ }^{9}$ a to ve snaze pojmenovat Čapkovy pokusy o znejistění samozřejmosti lidského poznání a s tím související nemožnosti, či přesněji omezené možnosti, dosažení pravdivého poznatku, činící tak všechna různorodá přesvědčení možnými. I proto jsou pochopitelné Čapkovy sympatie pro filozofii pragmatismu, která klade důraz na prozatímní povahu znalostí, oceňuje spíše přibližování se pravdě a zpřesňování znalosti. Avšak pragmatická skepse k představě absolutní pravdy Čapkem již tak jednoznačně přijímána není (stejně tak nelze pragmatický relativismus ztotožňovat $\mathrm{s}$ relativismem přisuzovaným Čapkovi, ${ }^{10}$ ačkoliv se tak někdy dělo ${ }^{11}$ ).

Čapek představuje pragmatické pojetí pravdy jako instrumentální teorii pravdy, ${ }^{12}$ při které je kritériem pravdivosti schopnost vyhodnocovat zkušenost a nabývat účinného a potřebného poznání. Instrumentalistický tón se však v Čapkových úvahách objevuje spíše v obhajobě racionalismu, kdy rozum chápe jako prvořadý nástroj lidského poznání, který však nenese zodpo-

7 Za všechny připomeňme asi nejčastěji citovanou povídku „Šlépěj“.

8 POHORSKÝ, M. Noetické romány Karla Čapka..., s. 522.

9 Za všechny srov. např. BRANŽOVSKÝ, J. Karel Čapek, světový názor a umění..., s. 122-125.

10 Srov. Čapkova kapitola „O relativismu“ z roku 1926 v práci $O$ věcech obecných čili Zóon politikon.

11 Známá obvinění v tomto smyslu vůči Čapkovi i v jeho době zaznívala např. od F. X. Šaldy nebo J. Durycha.

12 Srov. ČAPEK, K. Pragmatismus čili Filozofie..., s. 275. 
vědnost za své použití. ${ }^{13} \mathrm{~S}$ pragmatismem sdílel především požadavek na reálnou užitečnost rozumu a výsledků poznání. Představitelé pragmatismu se nicméně odhodlali přijmout i metafyzické důsledky svého pojetí pravdy. ${ }^{14}$ A zde se Čapek ocitá na rozcestí s americkou filozofií. Ve svém výkladu pravdy podle pragmatismu píše:

Tu bylo nutno učinit další krok: pravda není nic jiného než tato praktická cena; povaha pravdy není nic jiného než dobré fungování, osvědčování se, zkrátka jistá užitečná práce. Ale zároveň bylo nutno definitivně zrušit teoretickou hodnotu pravdy a přivésti v krajnost nominalism a relativism poznání. [...] Pak už přestává existovat poznání ve smyslu shody se zevní skutečností nebo zobrazení objektivní skutečnosti; pravda „neznamená“ nic skutečného, nýbrž jest něco prakticky skutečného, totiž skutečná práce, skutečný prospěch, skutečná hodnota. ${ }^{15}$

Čapek zde de facto naráží na své vlastní dilema: jak sloučit pro něj nezpochybnitelnou objektivní skutečnost s různorodými poznatky o ní. Jinými slovy, jak je možné, že ve světě, který je, jaký je, má „každý svoji pravdu“?

Nejdoslovněji Čapek vyjadřuje tento svůj vnitřní konflikt v Knize apokryfiu (1932) ve fiktivním rozhovoru Piláta s Josefem z Arimatie. ${ }^{16}$ Zatímco Josef hájí pravdu absolutní, zjevenou, nezpochybnitelnou, Pilát obhajuje pravdu jako něco, co má být prospěšné, co může být ve jménu užitku různorodé, ale co současně eo ipso nemůže být vnitřně rozporuplné. Připodobňuje pravdu k výstupu na kopec, ze kterého všechna samostatná pole vytváří jednolitou a smysluplnou krajinu. Různorodost našich poznatků je určena našimi poznávacími limity formulujícími „prozatímni“ a „soukromou“ pravdu, která je však součástí (mnohdy i přes rozporuplnost) pravdy absolutní. Až určitým druhem vyznání, vyjadřujícím přesvědčení o objektivní, věčné, neměnné pravdě, jsou pak závěrečná Pilátova slova:

13 „Kdyby nám někdo řekl, že ho zklamalo kladivo, jelikož jím nemohl požnout obilí nebo spravit díru v kalhotech, soudili bychom, že to zklamání je zbytečné a že kladivo není na to, aby se jím spravovaly kalhoty.“ ČAPEK, K. Zklamal nás rozum..., s. 584.

14 Asi nejznámější vymezení pravdy z pohledu pragmatismu pochází od W. Jamese: „Pravda je pro nás prostě kolektivní jméno pro verifikační proces, právě tak jako zdraví, bohatství, síla atd. jsou jména jiných životních procesů, o které také usilujeme, nebot se vyplácí. [...] Stručně řečeno je ,pravda pouze prostředek našeho myšlení, stejně jako ,dobré je pouze prostředek našeho jednání.“JAMES, W. Pragmatismus..., s. 112-113.

15 ČAPEK, K. Pragmatismus čili Filozofie..., s. 279.

16 Text s názvem „Pilátovo krédo“ byl poprvé publikován v Ruchu filosofickém roku 1920. 
Já věřím, věřím, horoucně věřím, že je pravda a že ji člověk poznává. Bylo by bláznivé myslit si, že je pravda jen k tomu, aby ji člověk nepoznal. Poznává ji, ano; ale kdo? Já, nebo ty, nebo snad každý? Já věřím, že každý na ni má podíl; i ten, kdo říká ano, i ten, kdo říká ne. Kdyby se ti dva spojili a rozuměli si, vznikla by tím celá pravda. ${ }^{17}$

Problémem je, že k této pravdě Piláta nevede rozum, ale víra.

Je-li tedy absolutní pravda tak ř́íkajíc „skrytá na nebesích“, obrací Čapek pohled na epistemologickou situaci člověka na zemi. Pilátovu otázku klade Čapek doslovně opět v roce 1922, když v článku „Co je pravda?“ popisuje soudní proces, který ztvárňuje situaci, v níž se častokrát ocitají i postavy Čapkových knih (letec v Povětroni, Juraj Hordubal, skladatel Foltýn). O stejném člověku vypovídá s upřímností a přesvědčením několik svědků, jejich výpovědi jsou však výrazně rozdílné. Důvod této „noeticky špatné situace“ vidí Čapek ve spleti nejméně tř́i možných př́ičin - citových, utilitárních a ideových. ${ }^{18}$ Jinak řečeno, každý máme svoji pravdu proto, že v cestě k objektivní skutečnosti stojí celá řada překážek, klamů a předsudků, spletitá křižovatka ne nepodobná baconovským idolům, která každého mluvčího zavede na odlišnou cestu. Čapek nedospívá tedy k odpovědi na otázku položenou v nadpisu článku, ale toliko k varování před unáhlenými úsudky. ${ }^{19}$

V naší „noeticky špatné situaci“ Čapek vidí jednak neblahý lidský úděl, který může být základem sporů a konfliktů, jednak znak lidskosti ve smyslu jedinečnosti vnímajícího subjektu, který vyžaduje toleranci a shovívavost nad člověkem jako tvorem odsouzeným k věčnému hledání pravdy. Z epistemologické otázky tak Čapek odvozuje humanistické závěry. Ve dvojici textů z roku 1922 „Nemohu mlčet“ a „Musím dále“ reagujících na vydání Továrny na Absolutno popisuje

17 ČAPEK, K. Pilátovo krédo..., s. 378.

18 Přŕčiny citové se vztahují k osobnímu povahovému a emocionálnímu ladění mluvčího - příkladem může být jak aktuální bolest zubů, která mluvčího vede k rozmrzelosti a negativismu, tak trvalý povahový rys, jako je třeba soucit, který naopak bude posuzované omlouvat. Utilitární příčiny charakterizuje Čapek jako opět osobní vztah mluvčího k posuzovanému, který může být ovlivněn pozitivně i negativně tím, že posuzovaný mluvčímu prospěl, nebo uškodil. Ideové prŕíčiny poukazují na souzení mluvčího ve vztahu k individuální škále, se kterou je posuzovaný srovnáván - Čapek jako př́íklad uvádí situaci, kdy něčí vlastnost srovnáváme vzhledem $\mathrm{k}$ běžnému výskytu této vlastnosti nebo $\mathrm{k}$ ideálnímu výskytu této vlastnosti (např́klad: ve srovnání se všemi bankéři byl tento bankéř ještě velkorysý, ale ve srovnání s tím, jak by měl být člověk velkorysý, už je považován za lakotného). ČAPEK, K. Co je pravda..., s. 233.

19 Srov. ČAPEK, K. Co je pravda..., s. 230-233. 
Čapek tyto dvě fasety v obdobných paralelách. Zaprvé charakterizuje pravdu jako danost, ke které se člověk přibližuje (a právě toto přibližování chápe jako cenné). Zadruhé dochází ke sporu rozdílných přesvědčení, která jsou subjektivně pokládána za pravdu. Zatřetí je nezbytné upřednostnit člověka samotného před jeho či mým přesvědčením. ${ }^{20}$ Čapkovo pozitivní „každý má pravdu“ je tedy nutno chápat spíše jako básnicky zesílené vyjádření myšlenky „každý má své přesvědčení“. Toto přesvědčení má být respektováno a tolerováno jako součást podstaty člověka, lidským úkolem by však mělo být usilování o pravdu absolutní. Tato obtížná noetická situace nedokonalého člověka, ne relativizace pravdy o sobě (dokonce ani ne pravda sama), jsou námětem Čapkovy literární tvorby a nutnou podmínkou porozumění jeho humanistickému apelu.

Já vím, že jiní lićí vrcholy dokonalosti, vysoké a náramné duše, absolutní pravdy, nadosobní ideály a podobné věci; co je však platna tato dokonalost, když z její výše se mi jeví život prvního bližního, kterého potkám, tím bezcennější, malichernější a nevykoupenějšíi? Povím vám, že sama humanita, sám socialismus srdce, sama láska k lidem musí být živena nekonečnou shovívavostí [...]. ${ }^{21}$

\section{Negativní: Co je pravda?}

Nebudeme-li tedy uvažovat nad podmínkami lidského poznávání, jak lze odpovědět na otázku „co je pravda“? Čapek, jak již bylo řečeno, uvažuje pravdu jako objektivní, trvalou a stálou entitu, ne nepodobnou platónské ideji. Přesto jeho rezervovaný postoj k idealistické filozofii, kterou opakovaně kritizoval pro její odtažitost od skutečnosti, zkušenosti a života vůbec, mu nedovoluje

20 Srovnejme pro př́íklad dvě pasáže z obou textů:

1) „A nyní - věřte mi prosím, že mluvím bez kliček - tato věta, že ,každý má pravdu', se může a musí ŕíci takéjinak: nikdo nemá pravdu. To neznamená, že nenípravdy nebo že pravda nestojí za to. Znamená tojen možnost smířiti se s tím, že jiný nevěřív mou Pravdu, neuctívá mého Dědka a neotročí mému Všelidskému Zájmu; smíriti se s tím potud, že ten jiný mi zůstává člověkem, a ne bestií, kterou mohu odstřelit nebo aspoň nenávidět. “ ČAPEK, K. Musím dále..., s. 415. 2) „Každý, kdo věří v nějakou Pravdu, myslí, že má proto nenávidět a zabíjet člověka, který věří v Pravdu jiné tovární známky. Je nějaký prostředek proti této nesmiřitelné nenávisti? Nevidím jiný než v poznání, že člověk je něco cennějšího než jeho ,pravda‘; že si můžeme rozuměti přes rozdíly vír, úpravy zelí nebo názorů o Janu Nepomuckém. " ČAPEK, K. Nemohu mlčet..., s. 414.

21 ČAPEK, K. Musím dále..., s. 416. 
nalézt v jakémkoliv modu substanční teorie dostatečnou odpověd'. V textu „Pereat mundus“ (1934) Čapek píše:

Filosofie je tak hodná, že nám staví na oči Absolutní Hodnoty; ale aby nebyly kompromitovány špatnou společností nás skutečných lidí a našich činů, klade je, abych tak řekl, na onen svět; ne do světa nečistého bytí, ale do oblasti čisté platnosti. Nehledejme Absolutních Hodnot v tom, co jest, ale v tom, co býti má; nejsou to žádné události ani vztahy ani city, nýbrž Normy. ${ }^{22}$

Čapek se pokouší najít vztah mezi člověkem a pravdou. Nesnází je, že špatná noetická situace člověka, reprezentovaná závěrem „každý má pravdu“ na straně jedné, stojí oproti až př́liš ve své dokonalosti uzavřenému ideálu pravdy, normě, ke které se člověk pouze přibližuje (proto věčná otázka „co je pravda?").

Prostorem, ve kterém jedině se může podle Čapka „setkávat“ vzdálený ideál a subjektivně poznávající člověk, je skutečnost. Ideál, jako vzor, projektovaný do světa, a člověk, jako součást světa, se tak navzájem setkávají. Kritériem pravdivosti je shoda se skutečností, jejíž součástí jsme, čímž získáváme spoluúčast na pravdě, a to i přes variabilitu našich přesvědčení (podobně jako se jednotlivá pole spojí v jednolitou krajinu v Pilátově představě v Apokryfech). V dalším příspěvku, „Hledají se jistoty“ (1934), to Čapek vyjadřuje následovně:

Každý poznává svou individuální hlavou, ale pravda, kterou chce najít, je obecně platná. To, co platí jenom pro jednu stranu, jednu víru, jeden národ, není ta pravda, která je věčným cílem lidského ducha. Budiž, ta pravda je ,jenom“ ideál; ale jakožto ideál není někde před námi, v utopické budoucnosti lidstva, nýbrž je už ted’ v nás a v našich poznatcích a činech stále splňována jako jejich imanentní cíl. Celá pravda je v tom nekonečném lidském usilování o pravdu. ${ }^{23}$

Právě nekonečnost lidského usilování o pravdu vede k negativnímu tónu Pilátovy otázky.

O pravdě jako korespondenci se skutečností hovoří Čapek v Kritice slov (1920).

22 ČAPEK, K. Misto pro Jonathana..., s. 152.

23 ČAPEK, K. Hledají se jistoty..., s. 544. 
Pravda se sice řídí podle skutečnosti, ale ještě lepší je, řídíli se skutečnost podle pravdy. ${ }^{24}$

Čapek se tak pokouší vyjádřit pochybnost, která souvisí s tradiční kritikou korespondenční teorie. Pravda je v Kritice slov vylíčena opět z negativního hlediska, když je charakterizována jako to, co je v běžné řeči (např́klad v obratu „krutá pravda“) nositelem špatných zpráv. Toto negativní vidění odrážející se v jazyce je podle Čapka vyjádřením jednak lidského postoje k pravdě jako čemusi náročnému až bolestnému, jednak výsledkem nebezpečné myšlenkové a jazykové lenosti. Čapek poukazuje opět, i když ne explicitně, na platónskou dichotomii mezi noésis a doxa, na rozdíl mezi tím, jaké věci jsou a jak se jeví. To, jak se jeví, se bezprostředně odráží v jazyce, který jako jeden z oněch „baconovských klamů“, před nimiž Čapek varuje, může dezinterpretovat významy slov. Můžeme se proto domnívat, že pojetí pravdy jako shody se skutečností je pro Čapka neslučitelný s pojetím pravdy jako shody s výrokem. Popisy světa mohou podobu světa záměrně i nezáměrně zkreslovat. Různé formy nepravd skryté v jazyce vnímal Čapek - s postupem doby a nástupem fašismu stále naléhavěji - jako velmi nebezpečné. ${ }^{25}$ Pojednává o tom rovněž v textu „Kousek pravdy“ (1928), kde různé formy nepravdivosti označuje za „nanejvýš nebezpečné“. Za jednu z nejrozšířenějších podob nepravdy chápe „přepínáni““ (respektive přehánění, zveličování), které pramení z neověření si stavu věcí vzhledem ke skutečnosti. Vyzývá k respektu ke skutečnosti v tom smyslu, že ačkoliv je pravda obtížně dosažitelná, lze omylnost lidského úsudku umenšit stálým osobním ověřováním skutečnosti. ${ }^{26}$

Opakující se Čapkovy poznámky o nesnadné dosažitelnosti pravdy a současně o lidské povinnosti stále o pravdu usilovat, nejsou pouze etickým apelem. Čapkův Pilát v Apokryfech říká: „,[...] je více pravdy v lidech nežli ve slovech“. ${ }^{27}$ Není to pouze další vyjádření nedůvěry v jazyk, ale i přesvědčení o přímé účasti člověka na metafyzické, absolutní pravdě. Vzájemné propojení absolutních hodnot ve smyslu norem a ideálů se skutečností, a tím i s lidmi, kteří jsou součástí této skutečnosti, může znamenat, že v lidech je i přes

24 ČAPEK, K. Kritika slov..., s. 47.

25 15. září 1938 vyšel v Lidových novinách jeden z posledních Čapkových textů „Modlitba za pravdu“.

26 „Ř́íá se, že pravda je jako zlato. Ano, zejména proto, že zlato také neleží na návsi jako husí trus, nýbrž musí se celkem pracně vykopávat nebo rýžovat. I pravda, at' o čemkoliv, se musí s jistým úsilím hledat a vydobývat.“ ČAPEK, K. Kousek pravdy..., s. 255.

27 ČAPEK, K. Pilátovo krédo..., s. 378. 
omylnost či neúplnou platnost jejich poznatků, která se prezentuje v jazyce, stejně tak jako ve skutečnosti „obsažena“ jistá esenciální pravda. Tedy nejen etická povinnost je hnací silou usilování o pravdu, k tomuto věčnému hledání člověka pudí i jistá metafyzická sounáležitost s pravdou samotnou.

\section{Korespondenční teorie pravdy}

Čapkova odpověd' na Pilátovu otázku se tedy zdá být jednodušší, než odborná literatura - i Čapek sám - naznačuje. Čapkovská sekundární literatura poukazuje na vliv pragmatismu, perspektivismu, relativismu, Čapek sám používá pojem pravda i tam, kde má na mysli poznávání, kritéria pravdivosti, přesvědčení. Ačkoliv je jasné, že Čapek je především spisovatel, a to spisovatel, kterému, jak sám říká, šlo vždy především o jasnost sdělení, jeho nadužívání a nepřesné užívání pojmu pravda porozumění nepomáhá. Nicméně srovnáním a rozborem jeho tvrzení se zdá, že Čapek mnoha zpo̊soby stále hovoří o tomtéž. Pravda je shoda se skutečností.

Korespondenční teorie má dlouhou historii a vícero podob. ${ }^{28}$ Podstatné rysy Čapkovo pojetí však splňuje. Čapek je přesvědčen o tom, že na otázku „co je pravda?" lze smysluplně odpovědět. Ačkoliv jde o náročný proces, nezpochybňuje ani možnost poznání. V neposlední řadě uznává objektivní skutečnost v duchu masarykovského realismu. Platónovo substanční pojetí pravdy je pro Čapka srovnatelné s pravdou zjevenou, teologickou. Jako taková je sice Čapkovi blízká a zůstává tušená v pozadí jeho pojetí pravdy, ale spadá podle něj spíše do oblasti víry, ne rozumu. Aristotelovo vymezení pravdy v Metafyzice jako vztahu mezi jsoucnem a skutečností („,...] všechno jest také k pravdě v takovém poměru, v jakém jest k jsoucnosti.“" ${ }^{29}$ ) je pozicí, která splňuje Čapkův obdobný, byt jinak formulovaný požadavek na řešení filozofických problémů z hlediska každodenního lidského života. Nicméně ve svém opatrném prrístupu k noetickým možnostem poznávacího subjektu, které jsou navíc vyjádřené nedokonalým jazykem, naráží na tradiční problém převoditelnosti skutečného stavu věcí na výroky, soudy a tvrzení o nich. Teoreticky by dnes bylo možné Čapkovo kritérium pravdy opřít o moderní

28 Historické kořeny korespondenční teorie leží u Aristotela (Metafyzika 1011b25) a u Platóna (Kratylos 385b2, Sofistés 263b). Obecně popisují vztah mezi skutečností a tvrzením, nicméně bez konkrétnější specifikace toho, jaká část skutečnosti je odpovědná za pravdivost tvrzení. Srov. DAVID, M. The Correspondece Theory of Truth...

Aristotelés. Metafyzika..., II, 1, 993b30-31, s. 67. 
sémantické analýzy pojmu „fakt“ jako obohacující ontologické entity, jejímž cílem je kompletace aristotelské, respektive Tarského explikace pravdy jako korespondence mezi jazykem a světem. Detailní rozbor faktu v jazyce moderní sémantiky je však mimo rozsah i cíl tohoto textu. Čapek neuvažuje pojem faktu, který by představoval protějšek tvrzení, vět a propozic. ${ }^{30}$ Tato specifikace korespondenční teorie pravdy, v níž pravda je shodou mezi tvrzeními a fakty, ${ }^{31}$ by mohla konkretizovat Čapkovu intuici o shodě skutečnosti s tvrzením o ní ${ }^{32}$ a nalézt uspokojivé řešení pro Čapkovu obavu z toho, že to, jak o věcech mluvíme, nelze považovat za totožné s tím, jaké věci jsou.

Čapkova odpověd' na Pilátovu otázku by mohla znít následovně: pravda je shoda se skutečností, která je nahlédnuta sub specie aeternitatis. Člověk tento zorný úhel získá jen obtížně, bolestně, podobně, jako když filozof opouští Platónovu jeskyni. Opřeme-li se o Platónovo podobenství, pak lze říct, že Čapek jistě vyzývá k úsilí o poznání pravého jsoucna, ale nezavrhuje ani stíny odrážející se na stěně jeskyně - byṫ jsou rozmazané, i v nich jsou hrubé obrysy a tvary skutečných věcí. Čapek nezpochybňuje svět mimo jeskyni, ale zamýšlí se nad situací těch, kteří zůstávají v ní.

\section{Seznam použitých zdrojů}

ARISTOTELÉS. Metafyzika. Přeložil Antonín KŘÍŽ. Praha: Jan Laichter 1946.

BRANŽOVSKÝ, Josef. Karel Čapek, světový názor a umění. Praha: Nakladatelství politické literatury 1963.

ČAPEK, Karel. Co je pravda? In ČAPEK, Karel. Od člověka k člověku I. Praha: Československý spisovatel 1988.

ČAPEK, Karel. Hledají se jistoty. In ČAPEK, Karel - POHORSKÝ, Miloš (ed.) - MACEK, Emanuel (ed.). O uměni a kultuře III. Praha: Československý spisovatel 1986.

ČAPEK, Karel. Kousek pravdy. In ČAPEK, Karel. Od clověka k člověku II. Praha: Československý spisovatel 1991.

ČAPEK, Karel. Kritika slov. Praha: Československý spisovatel 1991.

ČAPEK, Karel. Misto pro Jonathana! Praha: Symposium 1970.

ČAPEK, Karel. Musím dále. In ČAPEK, Karel - POHORSKÝ, Miloš (ed.) - MACEK, Emanuel (ed.). O uměni a kultuř II. Praha: Československý spisovatel 1985.

ČAPEK, Karel. Nemohu mlčet. In ČAPEK, Karel - POHORSKÝ, Miloš (ed.) - MACEK, Emanuel (ed.). O uměni a kultuře II. Praha: Československý spisovatel 1985.

30 Srov. KOLÁř, P. Pravda a fakt..., s. 123.

31 Srov. tamtéž, s. 179.

32 „Tvrzení je pravdivé díky tomu, že existuje fakt, který je pravdivým činí.“ Tamtéž. 
ČAPEK, Karel. Pilátovo krédo. In ČAPEK, Karel. Hovory s T.G. Masarykem; Kniha apokryfü; O věcech obecných čili Zóon politikon. Praha: Československý spisovatel 2012.

ČAPEK, Karel. Pragmatismus čili Filozofie praktického života. In ČAPEK, Karel POHORSKÝ, Miloš (ed.). Univerzitni Studie. Praha: Československý spisovatel 1987.

ČAPEK, Karel. Zklamal nás rozum? In ČAPEK, Karel - POHORSKÝ, Miloš (ed.) MACEK, Emanuel (ed.). O uměni a kultuře III. Praha: Československý spisovatel 1986.

DAVID, Marian. The Correspondece Theory of Truth . In Zalta, E. (ed.). The Stanford Encyclopedia of Philosophy [online]. Winter 2020 Edition [cit. 2021-04-30]. Dostupné z <https://plato.stanford.edu/entries/truth-correspondence/>.

JAMES, William. Pragmatismus. Nové jméno pro staré způsoby myšlení. Přeložil Radim BĚLOHRAD. Brno: CDK 2003.

KOLÁ̌̌, Petr. Pravda a fakt. Praha: Filosofia 2002.

OPELÍK, Jiří. Cesty za vědou. In OPELÍK, Jiří. Čtrnáctero praci o Karlu Čapkovi a ještě jedna o Josefu Čapkovi jako prívažek. Praha: Torst 2008.

POHORSKÝ, Miloš. Noetické romány Karla Čapka. Česká literatura. 1972, 20(6), s. 522-538.

ZOUHAR, Jan. Filozofie, světový názor, tvorba. In VLAŠÍN, Štěpán a kol. Kniha o Čapkovi. Praha: Československý spisovatel 1988.

ZOUHAR, Jan. Dějiny českého filozofického myšleni do roku 1968. Brno: Academicus 2008.

\section{Mgr. Hana Řehulková, Ph.D.}

Seminář estetiky, Filozofická fakulta, Masarykova univerzita

Arna Nováka 1, 60200 Brno, Česká republika

hanarehulkova@mail.muni.cz 